\title{
NITROGEN AND POTASSIUM FERTILIZATION OF POTATOES: EVALUATING NUTRIENT ELEMENT INTERACTIONS IN PETIOLES WITH RESPONSE SURFACES ${ }^{1}$
}

\author{
D. W. James ${ }^{2}$, R. L. Hurst, D. T. Westermann, and T. A. Tindall
}

\begin{abstract}
We studied the effects of fertilizer $\mathrm{N}$ and $\mathrm{K}$ rates on the nutrient concentrations in petioles of Russet Burbank potato grown on a low-K, low-Cl, highly calcareous Millville silt loam soil. Phosphate and $\mathrm{CaSO}_{4}$ were applied uniformly so that $\mathrm{P}$ and $\mathrm{S}$ did not limit plant growth. An incomplete factorial experimental design, utilizing 14 combinations of fertilizer $\mathrm{N}$ and $\mathrm{K}$, including two forms of $\mathrm{K}$, was used to develop a multi-dimensional regression model. This model was then used to produce response surfaces as an aid to analysis of the results and to illustrate the fertilizer treatment effects and their interactions on petiole chemistries. Nitrogen, $\mathrm{K}$ and $\mathrm{Cl}$ fertilizers had complex effects on petiole concentrations of $\mathrm{NO}_{3}-\mathrm{N}, \mathrm{SO}_{4} \mathrm{~S}, \mathrm{Cl}, \mathrm{K}, \mathrm{Ca}$ and $\mathrm{Mg}$. Nitrate-N and $\mathrm{Cl}$ were mutually antagonistic. Soil $\mathrm{N}$ had a large positive effect on petiole $\mathrm{K}$ and $\mathrm{Mg}$ levels and, to a lesser extent, petiole $\mathrm{Ca}$ levels. There was competition between $\mathrm{K}$ and $\mathrm{Mg}$ in petiole concentration. The sum of $\mathrm{K}, \mathrm{Ca}$ and $\mathrm{Mg}$ was essentially constant across fertilizer treatments and sampling times. The sum of $\mathrm{NO}_{3}-\mathrm{N}, \mathrm{SO}_{4}-\mathrm{S}$ and $\mathrm{Cl}$ was highly variable. The ratio of cations to anions ranged between three and five across fertilizer treatments and sampling times. The data indicate that calibration of the major nutrient element concentrations in potato petioles, as a guide to fertilization, requires knowledge of background soil fertility conditions with respect to $\mathrm{N}, \mathrm{K}, \mathrm{Cl}, \mathrm{Ca}$ and $\mathrm{Mg}$, and an understanding of the antagonisms and synergisms among these elements.
\end{abstract}

\section{Compendio}

Se estudiaron los efectos de las dosis de fertilizantes nitrogenados y potásicos sobre las concentraciones en los peciolos de papa Russet Burbank creciendo en suelo Millville aluvión-franco, altamente calcáreo, con bajos contenidos de $\mathrm{K}$ y Cl. Se aplicó uniformemente fosfato y $\mathrm{SO}_{4} \mathrm{Ca}$ de manera que el $\mathrm{P}$ y el $\mathrm{S}$ no limitaran el crecimiento de las plantas. El diseño experimental fue un factorial incompleto, utilizando 14 combinaciones de fertilizantes $\mathrm{N}$ y $\mathrm{K}$, incluyendo dos formas de $\mathrm{K}$, para desarrollar un modelo

${ }^{1}$ Contribution from the Utah Agricultural Experiment Station and from USDA-ARS. Utah Agricultural Experiment Station Journal Paper No. 4504.

${ }^{2}$ Respectively, Professor and Extension Soils Specialist, Plants Soils and Biometeorology, Utah State University, Logan, Utah 84322-4820; Professor Emeritus and Experiment Station Statistician, Utah State University; Soil Scientist, USDA-ARS, Soil and Water Management Research Unit, Kimberly, Idaho; Extension Soil Scientist, University of Idaho, Twin Falls. Accepted for publication November 13, 1993.

ADDITIONAL KEYWORDS: Potassium sources, nitrate, chloride, calcium, magnesium, ionic balance. 
de regresión de dimensión múltiple. Este modelo fue luego utilizado para producir superficies de respuesta como un medio para analizar los resultados e ilustrar los efectos del tratamiento con fertilizantes y sus interacciones sobrc las composiciones químicas de los peciolos. Los fertilizantes nitrogenados, potásicos y clorados $(\mathrm{N}, \mathrm{K}$ y $\mathrm{Cl}$ ) tuvieron efectos complejos sobre las concentraciones de $\mathrm{NO}_{3}-\mathrm{N}, \mathrm{SO}_{4}-\mathrm{S}, \mathrm{Cl}, \mathrm{K}$, Ca y $\mathrm{Mg}$. Los nitratos y el $\mathrm{Cl}$ fueron mutualmente antagónicos. El nitrógeno del suelo tuvo un efecto positivo prolongado sobre los niveles de $\mathrm{K}$ y $\mathrm{Mg}$ en los peciolos y en menor grado sobre los niveles de $\mathrm{Ca}$. Hubo competencia entre las concentraciones de $\mathrm{K}$ y $\mathrm{Mg}$ en el peciolo. La suma de $\mathrm{K}$, Ca y $\mathrm{Mg}$ fue esencialmente constante en todos los tratamientos con fertilizantes y momentos de toma muestras. La suma de $\mathrm{NO}_{3}-\mathrm{N}, \mathrm{SO}_{4}-\mathrm{S}$ y $\mathrm{Cl}$ fue muy variable. La relación de cationes a aniones varió entre tres y cinco en los tratamientos con fertilizantes y momentos de la toma de muestras. Los datos indican que la calibración de las concentraciones de los principales elementos nutrientes en los peciolos de papa, como una guía para la fertilización, requiere el conocimiento de los antecedentes de las condiciones de fertilidad del suelo con respecto a $N, K$, $\mathrm{Cl}$, Ca y $\mathrm{Mg}$ y de los antagonismos y sinergismos entre estos elementos.

\section{Introduction}

The nutrient concentration of plant tissues, together with diagnostic soil tests, are used to help achieve least cost per unit of crop production. Plant analysis is based on the principle that the concentration of nutrients within the plant, or one of its parts, integrates all of the factors affecting plant growth, including the availability of elements in the soil (15). Plant analysis as an aid to fertilization of vegetable crops, including potato, was discussed by Geraldson and Tyler (5). They summarized the nutrient concentrations associated with deficiency and sufficiency and the relationship of plant growth stage, cultivar, soil fertilization and nutrient interactions in relation to optimal levels of nutrients. Genetic potential (cultivar) governs nutrient concentrations in plants as well as crop yield potential (9).

Potassium chloride is an economical source of fertilizer $\mathrm{K}$ but $\mathrm{Cl}$ may confound $\mathrm{K}$ soil-plant nutrient relationships. Chloride has three different plant functions: (a) as a plant nutrient; (b) through competition with other nutrients in plant up-take; and (c) as a component of the cellular osmotica. Chloride is not a frequent subject of field soil fertility investigations, but $\mathrm{Cl}$ was included here because the soil and irrigation water at the experimental site were very low in this element.

Chloride is an essential nutrient element for various higher plants (1). Choride deficiencies have been reported for potato (4), red clover (22) and kiwifruit (18), all of which were done under greenhouse conditions.

Chloride deficiency in field-grown plants is rare even though othe! functions of $\mathrm{Cl}$ in plants are quite general. For example, there is a striking interaction (mutual antagonism) between $\mathrm{Cl}$ and $\mathrm{NO}_{3}$ for plant uptakc i" 
potato $(7)$; barley $(3)$; sugarbeet and fodderbeet $(8,14)$; bean and snapbean (23); kiwifruit (18); and tomato (10).

Interactions among inorganic anions $\left(\mathrm{Cl}, \mathrm{SO}_{4}^{2}, \mathrm{NO}_{3}^{-}, \mathrm{H}_{2} \mathrm{PO}_{4}^{-}\right)$occur both at the soil-root interface and within the plant cells (6). Hiatt and Leggett (6) state also that endogenous interactions include organic anions and a feedback mechanism that influences nutrient element uptake by roots.

Whereas $\mathrm{Cl}$ is required in small amounts by plants, under some conditions it may accumulate in large amounts in plants (2) and $\mathrm{Cl}$ toxicity may occur in sensitive crops such as soybean, even under non-saline conditions (17). Chloride uptake lessens the production of organic anions by the plant (2). It is not known whether there is a savings in metabolic energy when $\mathrm{Cl}$ replaces some organic anions.

One of the primary roles of $\mathrm{K}$ in the plant is as an osmoticum and normally $\mathrm{Cl}$ acts as a non-metabolized counter-ion to $\mathrm{K}(2)$. It is apparent therefore, that the roles of $\mathrm{Cl}$ in the plant are strongly affected by other elements. Nevertheless, Flowers (2) emphasized that $\mathrm{Cl}$ has a unique role in plant nutrition since a deficiency results in visual symptoms and growth retardation.

The research reported here sought to determine the optimum $\mathrm{N}$ and $\mathrm{K}$ soil fertility conditions for production of Russet Burbank potato growing on a low-K, calcareous soil. The $\mathrm{Cl}-\mathrm{NO}_{3}$ interactions, the $\mathrm{K}-\mathrm{Ca}-\mathrm{Mg}$ interactions, and the cation and anion balance in the petioles of Russet Burbank potatoes are described. Other papers in this series examine the fertilizer treatment effects on tuber yield and specific gravity (20) and the effects on tuber sugars and starch (21).

TABLE 1.-Experimental design; fourteen treatment combinations in two incomplete $N x K$ factorials based on $K$ source. ${ }^{2}$

\begin{tabular}{|c|c|c|c|c|c|}
\hline \multirow{2}{*}{\multicolumn{2}{|c|}{$\frac{\mathrm{K}}{\text { Source } \mathrm{kg} / \mathrm{ha}}$}} & \multicolumn{4}{|c|}{$\mathrm{kg} \mathrm{N} / \mathrm{ha}$} \\
\hline & & 0 & 112 & 224 & 336 \\
\hline & & & nent $n$ & - & \\
\hline \multirow[t]{5}{*}{$\mathrm{Cl}$} & 0 & 1 & & 2 & \\
\hline & 112 & & 3 & & 4 \\
\hline & 224 & 5 & & 6 & \\
\hline & 336 & & & & \\
\hline & 448 & & 7 & & 8 \\
\hline & --- & --- & --- & -- \\
\hline \multirow[t]{5}{*}{$\mathrm{SO}_{4}$} & 0 & 1 & & 2 & \\
\hline & 112 & & 9 & & 10 \\
\hline & 224 & 11 & & 12 & \\
\hline & 336 & & & & \\
\hline & 448 & & 13 & & 14 \\
\hline
\end{tabular}

'Treatments 1 and 2 where repeated in the $\mathrm{Cl}$ and $\mathrm{SO}_{4}$ subsets for generating the respective response surfaces. $\mathrm{N}$ was supplied as urea. $\mathrm{K}$ was supplied respectively as $\mathrm{KCl}$ and $\mathrm{K}_{2} \mathrm{SO}_{4}$. Design consists of two interlocking $2 \times 2$ factorials. 
Soil and Crop

\section{Materials and Methods}

Russett Burbank potatoes were grown near Logan, Utah, on a Millville silt loam (coarse silty carbonatic mesic typic Haploxerolls), a well drained, strongly calcareous soil formed from dolomitic parent material. Characteristics of the soil and irrigation water at the site are reported by Westermann et al. (20). Briefly, this soil was low in $\mathrm{K}$ fertility and the irrigation water was very low in dissolved $\mathrm{K}, \mathrm{Cl}$ and $\mathrm{SO}_{4}$.

\section{Experimental Design}

These experiments were specially designed to produce response surfaces of the dependent variables (petiole nutrient element concentrations in this paper) to aid in evaluation of the interactions among potato nutritional factors. Fertilizer treatment combinations and other features of the experimental design are given in Table 1: Fourteen $\mathbf{N}$ and $\mathrm{K}$ fertilizer treatment combinations were arranged in an incomplete factorial design with four replications. The experimental design is described in more detail elsewhere (20). Phosphorus as 0-45-0 (50 kg P ha-1) and $S$ as gypsum (30 kg S ha-1) were applied uniformly to avoid deficiencies of these elements in the crop.

\section{Petiole Analysis}

Petiole samples were collected 61, 79 and 106 days after planting in 1988 and 74 and 101 days after planting in 1989. About 30 petioles, the fourth leaf from the growing tip, were collected from the middle two rows of each plot.

The petioles were dried at $60 \mathrm{C}$, and ground to pass a 40 mesh screen. The petiole tissue was analyzed for $\mathrm{NO}_{3}-\mathrm{N}$ by a specific-ion electrode (13) .

TABLE 2.-Regression model used to produce response surfaces of the dependent variables. ${ }^{a}$

\begin{tabular}{|c|c|}
\hline $\begin{array}{l}\text { Regression } \\
\text { Coefficient }\end{array}$ & $\begin{array}{l}\text { Main and } \\
\text { interaction effects }\end{array}$ \\
\hline bo & overall mean \\
\hline bl & $\mathrm{N}$ \\
\hline b2 & $\mathbf{K}$ \\
\hline b3 & $\mathrm{Cl}_{-\mathrm{SO}_{4}(\mathrm{a})}$ \\
\hline b4 & $\mathrm{N}^{2}$ \\
\hline b5 & $\mathrm{K}^{2}$ \\
\hline b6 & NxK \\
\hline b7 & $\mathrm{NxCl}-\mathrm{SO}_{4}$ \\
\hline b8 & $\mathrm{KxCl}-\mathrm{SO}_{4}$ \\
\hline b9 & $\mathrm{N}^{2} \mathrm{xCl}_{-} \mathrm{SO}_{4}$ \\
\hline b10 & $\mathrm{K}^{2} \times \mathrm{Cl}_{-} \mathrm{SO}_{4}$ \\
\hline bll & $\mathrm{NxKxCl}_{-} \mathrm{SO}_{4}$ \\
\hline
\end{tabular}

${ }^{\mathrm{a}} \mathrm{Read} \mathrm{Cl}-\mathrm{SO}_{4}$ as $\mathrm{Cl}$ or $\mathrm{SO}_{4}$. These were represented in the model as categorical variables, i.e. $(+1)$ and $(-1)$ respectively. 
The tissue was dry ashed at $500 \mathrm{C}$ for $6 \mathrm{~h}$ and the residue dissolved in $50 \mathrm{ml}$ of $0.2 \mathrm{~N} \mathrm{HNO}_{3}$. This digest was analyzed for $\mathrm{P}(11) ; \mathrm{K}, \mathrm{Ca}$, and $\mathrm{Mg}$ (atomic absorption spectrophotometry); and $\mathrm{Cl}$ and $\mathrm{S}$ by flow injection analysis (12; Method Nos. 12-117-07-1-A and 12-116-10-1-C, respectively.) Nitrate-N is reported as $\mathrm{mg} / \mathrm{g}$ (parts per thousand) dry weight. All other elements are reported as percent dry weight. For some comparisons the petiole nutrient concentrations were converted to millimoles charge per gram $\left(\mathrm{mmol}_{\mathrm{c}} / \mathrm{g}\right)$ and from this the sum of cations, sum of anions and their ratios were computed.

\section{Statistical Analyses}

Preliminary two-way analyses of variance were calculated on the potato petiole chemistry parameters. Where there were significant treatment effects, the treatment means were used to generate a regression equation based on the first order regression model of Table 2. The regression equation was used to interpolate the missing cells in the incomplete factorials (Table 1 ). In other words, the 14 treatment combinations were used to generate 20 estimated treatment means in each of the $\mathrm{N}-\mathrm{KCl}$ and $\mathrm{N}-\mathrm{K}_{2} \mathrm{SO}_{4}$ response surfaces.

Only a portion of the response surfaces arising from the experiments are presented in the results to conserve space. Westermann et al. (20) emphasize that even though there was considerable range in $\mathrm{N}$ and $\mathrm{K}$ fertilizer rates, the expected optimum $\mathrm{N}$ and $\mathrm{K}$ combinations were located under the central region of the tuber yield response surface.

The "goodness of fit", i.e. $\mathrm{R}^{2}$, between the measured treatment means and their counterparts predicted by the model, was computed.

\section{Results and Discussion}

Table 3 summarizes the analysis of variance for the fertilizer $\mathrm{N}, \mathrm{KCl}$ and $\mathrm{K}_{2} \mathrm{SO}_{4}$ treatment main effects on individual nutrient element concentrations

TABLE 3.-Analysis of variance: Treatment main effects on petiole nutrient element concentrations.

\begin{tabular}{|c|c|c|c|c|c|}
\hline \multirow{2}{*}{$\begin{array}{l}\text { Dependent } \\
\text { variable }\end{array}$} & \multicolumn{5}{|c|}{ Sampling time-Year } \\
\hline & $1-88$ & $2-88$ & $3-88$ & $1-89$ & $2-89$ \\
\hline & & & -F ratio & & \\
\hline $\mathrm{NO}_{3}$ & 32.45 & 27.90 & 27.99 & 140.41 & $\mathbf{5 7 . 5 7}$ \\
\hline $\mathrm{Cl}^{3}$ & 51.13 & 25.36 & 31.54 & 103.39 & 6.46 \\
\hline $\mathbf{S}$ & 2.42 & 10.77 & 11.36 & 8.47 & 8.60 \\
\hline $\mathbf{K}$ & 23.71 & 24.25 & 14.76 & 7.27 & 7.16 \\
\hline $\mathrm{Ca}$ & 2.18 & 2.99 & 6.61 & 0.85 & 5.32 \\
\hline $\mathrm{Mg}$ & 8.09 & 5.49 & 9.28 & 3.83 & 2.73 \\
\hline ¿Cations & 8.63 & 4.16 & 4.38 & 0.85 & 2.97 \\
\hline EAnions & 19.60 & 18.96 & 10.78 & 48.15 & 6.99 \\
\hline $\bar{\Sigma}$ Cations/LAnions & 20.15 & 21.27 & 10.51 & 20.46 & 1.81 \\
\hline
\end{tabular}

$F_{01}=3.42 ; F_{(05)}=2.34$. 
TABLE 4.-Multiple correlation coefficients for petiole chemistries; comparing predicted treatment means with observed treatment means.

\begin{tabular}{|c|c|c|c|c|c|}
\hline \multirow{2}{*}{$\begin{array}{l}\text { Petiole } \\
\text { parameter }\end{array}$} & \multicolumn{5}{|c|}{ Days after planting/year } \\
\hline & $61 / 88$ & $79 / 88$ & $106 / 88$ & $74 / 89$ & $101 / 89$ \\
\hline & & & $-\mathrm{R}^{2}$ & & \\
\hline $\mathrm{NO}_{3}-\mathrm{N}$ & 0.985 & 0.996 & 0.951 & 0.980 & 0.968 \\
\hline $\mathrm{Cl}^{3}$ & 0.985 & 0.999 & 0.959 & 0.988 & 0.986 \\
\hline $\mathbf{K}$ & 0.965 & 0.972 & 0.983 & 0.929 & 0.943 \\
\hline $\mathrm{Ca}$ & 0.806 & 0.984 & 0.956 & 0.615 & 0.933 \\
\hline $\mathbf{M g}$ & 0979 & 0.983 & 0.976 & 0.857 & 0.979 \\
\hline $\mathrm{SO}_{4}-\mathrm{S}$ & 0.812 & 0.945 & 0.981 & 0.975 & 0.945 \\
\hline$\Sigma$ Cations & 0.949 & 0.958 & 0.981 & 0.962 & 0.908 \\
\hline EAnions & 0.982 & 0.993 & 0.981 & 0.962 & 0.908 \\
\hline $\bar{\Sigma}$ Cations/LAnions & 0963 & 0.984 & 0.946 & 0.911 & 0.849 \\
\hline
\end{tabular}

${ }^{2}$ All $R^{2}$ significant at $P \leq 0.01$.

for each sampling time. As indicated, treatment effects were generally signifi-

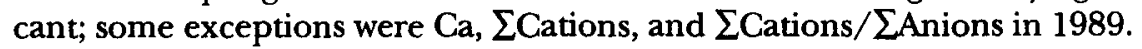

TABLE 5.-Comparison of predicted (PR), observed (OB) and standard error of the estimated mean (SE) for selected petiole nutrient element concentrations. First sampling, 1988.

\begin{tabular}{|c|c|c|c|c|}
\hline & & $\mathrm{NO}_{3}-\mathrm{N}$ & & \\
\hline $\mathrm{kg} \mathrm{K} / \mathrm{ha}$ & & & & \\
\hline & 0 & 112 & 224 & 336 \\
\hline 0 & PR $9.67 \quad(0.65)$ & $16.91 \quad(0.58)$ & $20.18 \quad(0.60)$ & $19.47(1.05)$ \\
\hline & OB 9.85 & & 19.40 & \\
\hline 112 & PR $8.47 \quad(0.53)$ & $15.86(0.48)$ & $19.29(0.45)$ & $18.74 \quad(0.66)$ \\
\hline & $\mathbf{O B}$ & 16.82 & & 19.35 \\
\hline 224 & PR $7.68 \quad(0.62)$ & $15.23(0.53)$ & $18.80 \quad(0.56)$ & $18.40 \quad(0.60)$ \\
\hline & OB 7.05 & & 18.25 & \\
\hline 336 & PR $7.30 \quad(0.83)$ & $15.00 \quad(0.49)$ & $18.73(0.54)$ & $18.48 \quad(0.60)$ \\
\hline 448 & PR 7.32 (1.29) & $15.18 \quad(0.68)$ & $19.06 \quad(0.58)$ & $18.97(0.69)$ \\
\hline & OB & 15.55 & & 18.80 \\
\hline & & K \% & & \\
\hline $\mathrm{kg} \mathrm{K} / \mathrm{ha}$ & & & & \\
\hline & 0 & 112 & 224 & 336 \\
\hline 0 & PR $5.46 \quad(0.16)$ & $(.14)$ & $5.06 \quad(0.14)$ & $4.76 \quad(0.25)$ \\
\hline & OB 5.65 & & 4.78 & \\
\hline 112 & PR $6.51 \quad(0.12)$ & $6.48(0.12)$ & $6.38(0.11)$ & $6.22(0.16)$ \\
\hline & OB & 6.52 & & 6.42 \\
\hline 224 & PR $7.13(0.15)$ & $7.243(0.13)$ & $7.28 \quad(0.13)$ & $7.26 \quad(0.14)$ \\
\hline & OB 6.88 & & 7.35 & \\
\hline 336 & PR $7.33 \quad(0.20)$ & $7.58 \quad(0.12)$ & $7.75 \quad(0.13)$ & $7.87 \quad(0.14)$ \\
\hline 448 & PR $7.10 \quad(0.31)$ & $7.49(0.16)$ & $7.80(0.14)$ & $8.06 \quad(0.16)$ \\
\hline & OB & 7.65 & & 7.92 \\
\hline
\end{tabular}




\begin{tabular}{|c|c|c|c|c|c|c|c|c|}
\hline & & & & $\mathrm{Cl} 9$ & & & & \\
\hline $\mathrm{kg} \mathrm{K} / \mathrm{ha}$ & & & & & & & & \\
\hline & & 0 & & 12 & & 224 & 33 & \\
\hline 0 & 0.74 & $(0.09)$ & 0.14 & $(0.08)$ & -0.05 & $(0.08)$ & 0.18 & $(0.14)$ \\
\hline & OB 0.62 & & & & 0.11 & & & \\
\hline 112 & PR 1.67 & $(0.07)$ & 0.92 & $(0.06)$ & 0.58 & $(0.06)$ & 0.65 & $(0.09)$ \\
\hline & $\mathbf{O B}$ & & 0.94 & & & & 0.54 & \\
\hline 224 & PR 2.41 & $(0.08)$ & 1.50 & $(0.07)$ & 1.02 & $(0.07)$ & 0.94 & $(0.08)$ \\
\hline & OB 2.56 & & & & 0.93 & & & \\
\hline 336 & PR 2.96 & $(0.11)$ & 1.91 & $(0.06)$ & 1.27 & $(0.07)$ & 1.04 & $(0.08)$ \\
\hline 448 & PR 3.34 & $(0.179)$ & 2.13 & $(0.09)$ & 1.34 & $(0.08)$ & 0.96 & $(0.09)$ \\
\hline & OB & & 2.04 & & & & 1.05 & \\
\hline & & & & Ion $\mathrm{R}$ & . & & & \\
\hline $\mathrm{kg} \mathrm{K} / \mathrm{ha}$ & & & & & & & & \\
\hline 0 & 3.24 & $(0.09)$ & 2.58 & $(0.08)$ & 2.22 & $(0.08)$ & 2.16 & $(0.14)$ \\
\hline & OB 3.34 & & & & 2.16 & & & \\
\hline 112 & PR 2.96 & $(0.07)$ & 2.38 & $(0.06)$ & 2.09 & $(0.06)$ & 2.09 & $(0.09)$ \\
\hline & OB & & 2.24 & & & & 2.13 & \\
\hline 224 & PR 2.73 & $(0.08)$ & 2.21 & $(0.07)$ & 2.00 & $(0.07)$ & 2.07 & $(0.08)$ \\
\hline & OB 2.65 & & & & 2.14 & & & \\
\hline 336 & PR 2.53 & $(0.11)$ & 2.09 & $(0.06)$ & 1.94 & $(0.07)$ & 2.09 & $(0.08)$ \\
\hline 448 & PR 2.38 & $(0.17)$ & 2.01 & $(0.09)$ & 1.94 & $(0.08)$ & 2.15 & $(0.09)$ \\
\hline & $\mathbf{O B}$ & & 2.07 & & & & 2.09 & \\
\hline
\end{tabular}

The regression model predicted nutrient element concentrations for all $\mathrm{N}$ and $\mathrm{K}$ rate and source combinations in the complete $4 \mathrm{~N} \times 5 \mathrm{~K}$ complete factorial (Table 1). The "goodness of fit" $\left(R^{2}\right)$ for each sampling time is shown in Table 4. "Goodness of fit" ranged from 0.615 to 0.988 , averaging 0.946 across all sampling times and years. The model was also efficient in estimating tuber yields and specific gravities; $\mathbf{R}^{2}$ ranged between 0.72 and 0.98 for these parameters (20). The predicted treatment mean, the observed treatment mean and the standard error of the estimate for selected parameters in 1988 are presented in Table 5. For economy of space other parameters and sampling times in 1988 and 1989 are not given but the response surfacegenerating model was equally reliable for all other data sets.

The following figures illustrate the many treatment effects and interactions that were encountered. Response surfaces omitted because of space were equally significant and supportive of the final conclusions. The surface of each three-dimensional graph is rotated so that it slopes downward to the viewer to avoid concealing lines. Accordingly, the orientation of each figure may vary to provide the clearest view of each data set, as does the scaling of the axes. It will be noted that conformation of the response surface changes from element to element and among sampling times. In this manner of presentation the individual treatment means are less important than are the relationships among means, i.e. interactions.

Figure 1 shows the treatment effects on petiole- $\mathrm{NO}_{3}-\mathrm{N}$. The base level of petiole- $\mathrm{NO}_{3}$ was higher in 1988 than in 1989 (Fig. la vs $1 \mathrm{~b}$ ), partially 

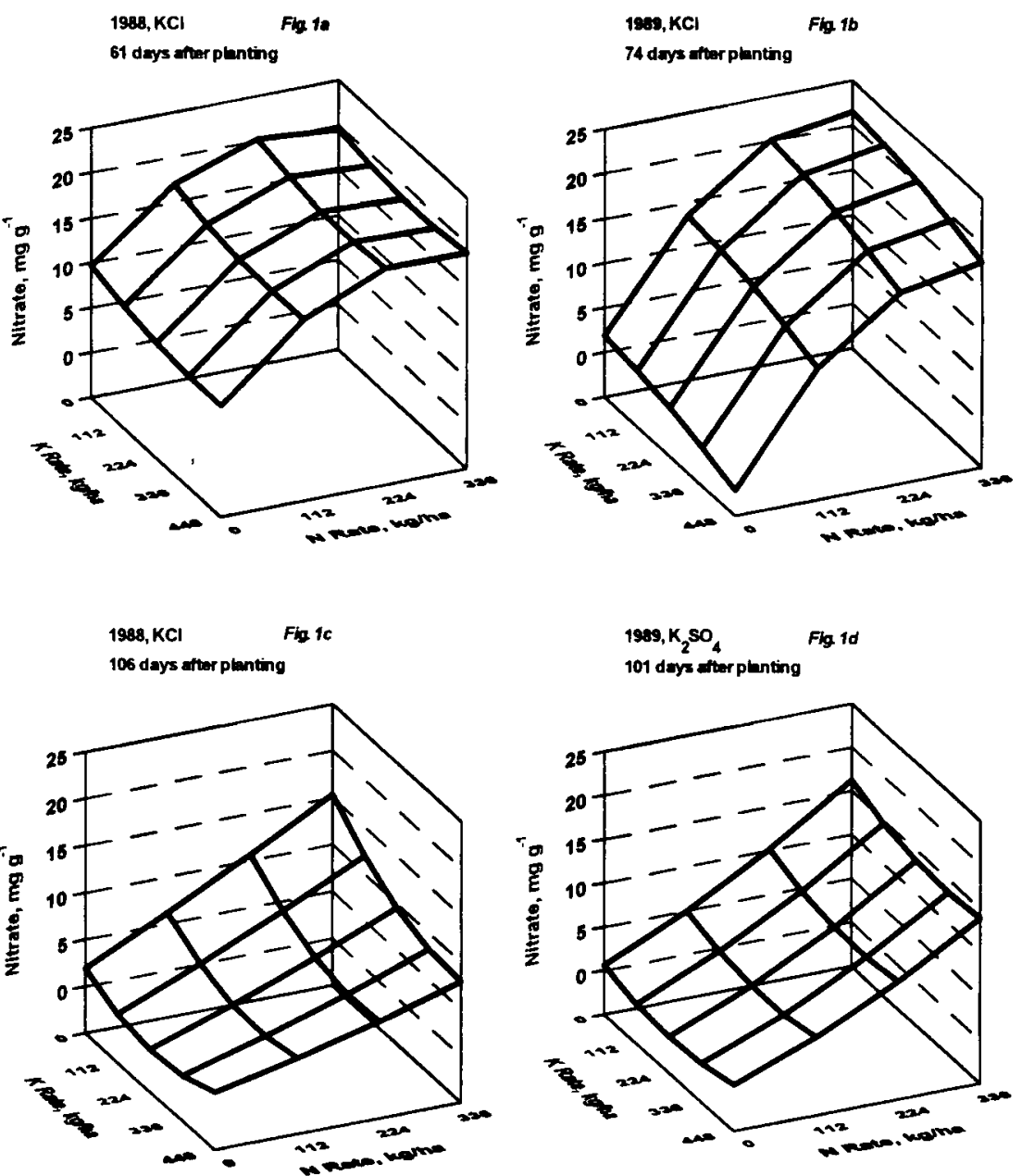

FIG. 1. Petiole $\mathrm{NO}_{3}-\mathrm{N}$ responses to $\mathrm{N}$ and $\mathrm{KCl}(\mathrm{a}, \mathrm{b}, \mathrm{c})$ and $\mathrm{K}_{7} \mathrm{SO}_{4}(\mathrm{~d})$ fertilizers at selected sampling times in 1988 and 1989.

because the first sampling was earlier in 1988. Petiole-NO $\mathrm{N}_{3}$ decreased rapidly with time (Fig. la vs lc). In both seasons petiole- $\mathrm{NO}_{3}$ increased with fertilizer-N to a maximum of about $20 \mathrm{mg} / \mathrm{g}$ at $224 \mathrm{~kg} \mathrm{~N} / \mathrm{ha}$. Fertilization with $\mathrm{KCl}$ sharply decreased $\mathrm{NO}_{3}-\mathrm{N}$ petiole levels after the first sampling. Fertilization with $\mathrm{K}_{2} \mathrm{SO}_{4}$ did not significantly decrease petiole $\mathrm{NO}_{3}$ levels.

Initially the fertilizer- $\mathrm{N}$ was urea, but nitrification converts the bulk of the fertilizer-N to $\mathrm{NO}_{3}$ in Millville silt loam soil within about three weeks after application. Accordingly, the plant would be exposed to essentially $100 \%$ of the fertilizer- $\mathrm{N}$ as $\mathrm{NO}_{3}$ for the most of the growing season.

Petiole-Cl concentrations increased with the fertilizer- $\mathrm{KCl}$ rate and decreased by $45 \%$ to $85 \%$ with fertilizer- $\mathrm{N}$ in both seasons, depending on the soil treatment (Figs. $2 \mathrm{a}$ and $\mathrm{c}$ ). Whereas $\mathrm{NO}_{3}-\mathrm{N}$ generally decreased with

4



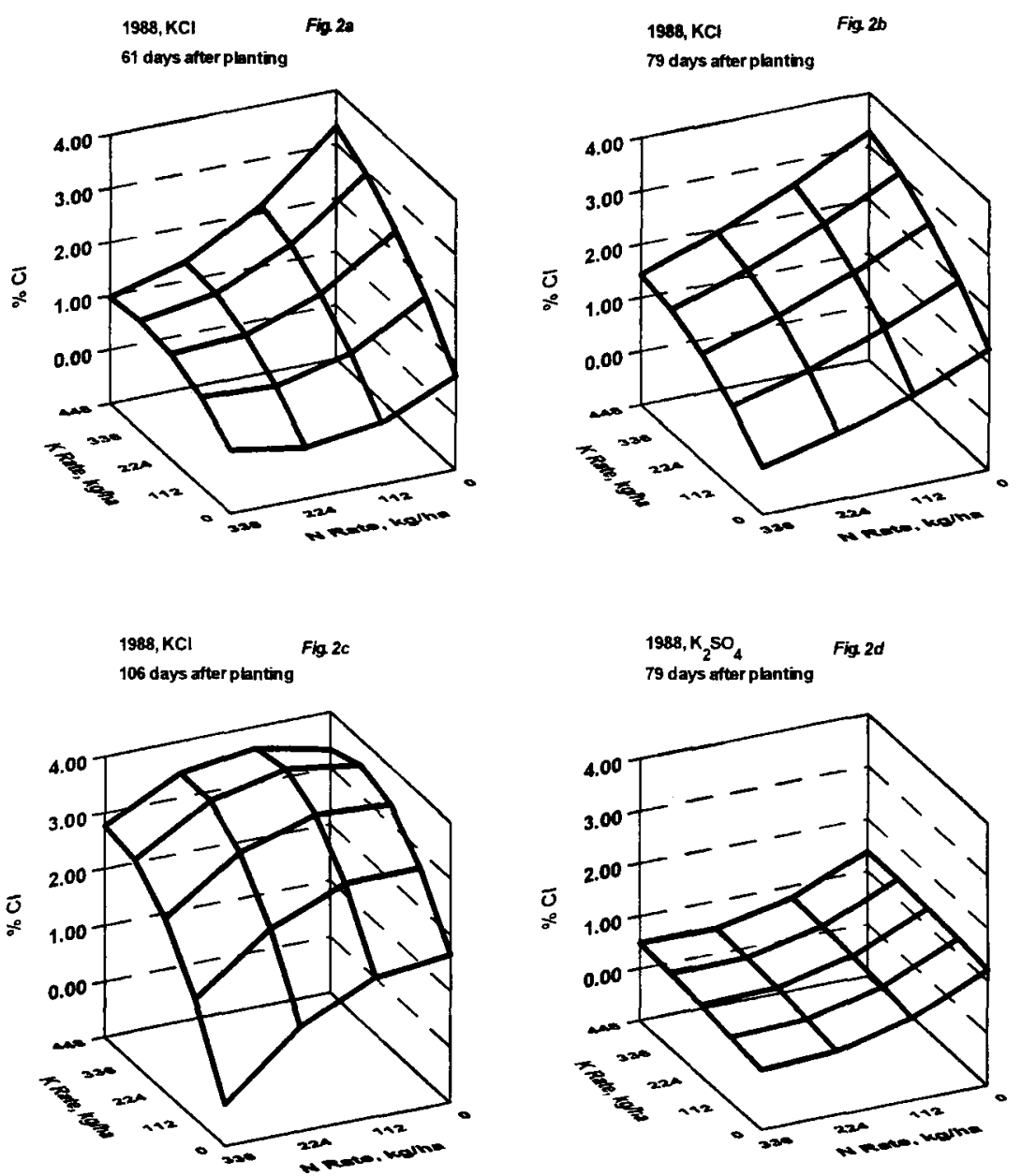

FIG. 2. Petiole $\mathrm{Cl}$ response to $\mathrm{N}$ and $\mathrm{KCl}(\mathrm{a}, \mathrm{b}, \mathrm{c})$ and $\mathrm{K}_{2} \mathrm{SO}_{4}$ fertilizers at selected sampling times in 1988.

time (Fig. 1), petiole-Cl increased (Fig. 2). Petiole-Cl tended to increase with fertilizer $\mathrm{K}_{2} \mathrm{SO}_{4}$ (and decrease with fertilizer- $\mathrm{N}$ ), probably because of the small amount of $\mathrm{Cl}$ present in the $\mathrm{K}_{2} \mathrm{SO}_{4}$ (Fig. 2d). The overall results in Figs. 1 and 2 show that the $\mathrm{NO}_{3}-\mathrm{Cl}$ antagonism is reciprocal. The large effects of fertilizer-Cl on petiole-NO $\mathrm{N}_{3}$ has been observed elsewhere $(7,10)$. Unpublished data from Kimberly, Idaho show that the $\mathrm{NO}_{3}-\mathrm{Cl}$ antagonism occurred at relatively high background $\mathrm{Cl}$ levels also.

Gausman et al. (4) reported that $\mathrm{Cl}$ deficiency was seen in potato where leaf tissue contained 0.0143 to $0.0381 \mathrm{mmol}_{\mathrm{c}} \mathrm{Cl} / \mathrm{g}$ corresponding to $0.051 \%$ and $0.13 \% \mathrm{Cl}$ dry weight. In our study $\mathrm{Cl}$ was as low as $0.068 \%$ in individual plots. Petiole-Cl averaged $0.108 \%$ where $\mathrm{KCl}$ was not applied. It appears that $\mathrm{Cl}$ might have been deficient in this low-Cl field environment where it 

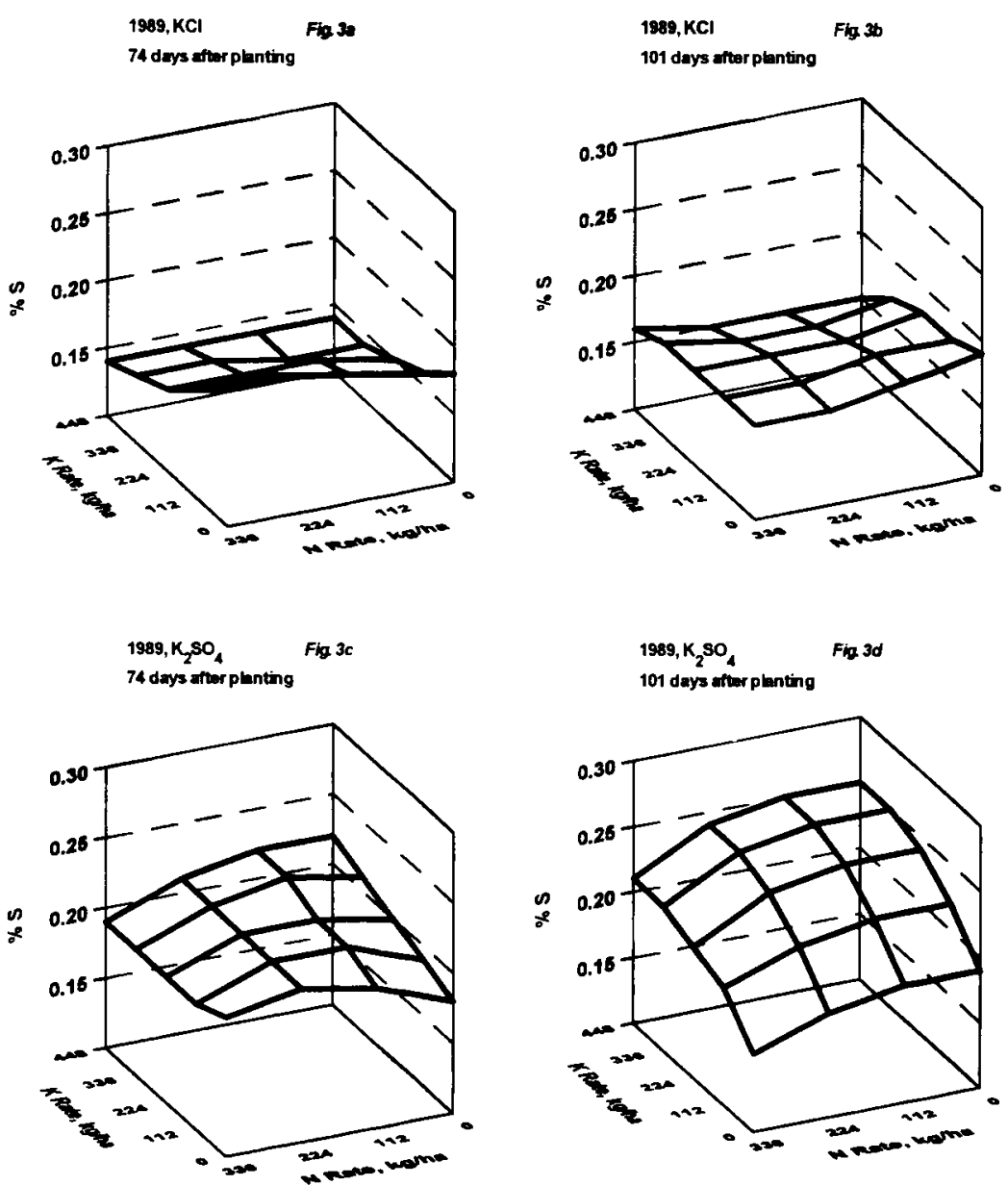

FIG. 3. Petiole $\mathrm{SO}_{4}-\mathrm{S}$ responses to $\mathrm{N}$ and $\mathrm{KCl}(a, b)$ and $\mathrm{K}_{2} \mathrm{SO}_{4}(c, d)$ fertilizers at selected sampling times in 1989.

was not included in the fertilizer.

The $\mathrm{NO}_{3}-\mathrm{Cl}$ antagonism is of considerable practical consequence. Although it seemed to have little effect on tuber yield, it did affect specific gravity (20) and markedly affected tuber starch, sucrose and reducing sugar (21). Our results indicate that petiole analyses, as a guide to $\mathrm{N}$ fertilization of potatoes, should be calibrated against background levels of $\mathrm{Cl}$ in the environment.

Fertilizer treatment effects on petiole $\mathrm{SO}_{4}-\mathrm{S}$ are illustrated in Fig. 3. Petiole-SO ${ }_{4}$ tended to decrease with $\mathrm{KCl}$ rates but there was little apparent effect of fertilizer-N. By contrast, petiole- $\mathrm{SO}_{4}$ increased markedly with fertilizer-S and decreased with fertilizer-N (Fig. 3d), possibly because of dilution in the more vigorous plant growth associated with fertilizer-N. The $\mathrm{NO}_{3}-\mathrm{SO}_{4}$ competition was clearly not as pronounced as that for $\mathrm{NO}_{3}-\mathrm{Cl}$. As 

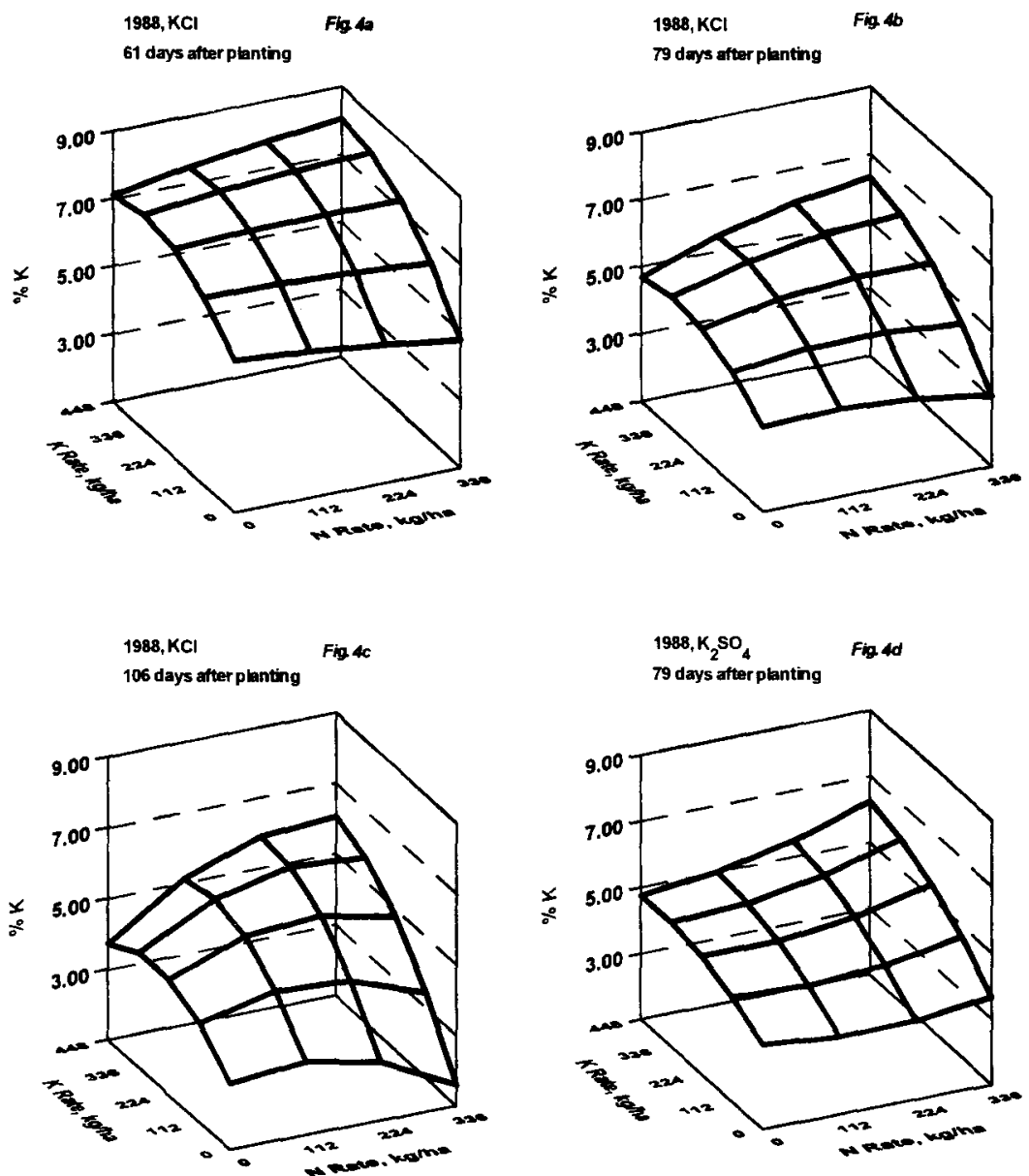

FIG. 4. Petiole $\mathrm{K}$ responses to $\mathrm{N}$ and $\mathrm{KCl}(\mathrm{a}, \mathrm{b}, \mathrm{c})$ and $\mathrm{K}_{2} \mathrm{SO}_{4}(\mathrm{~d})$ fertilizers at selected sampling times in 1988.

stated above, $\mathrm{CaSO}_{4}$ was applied uniformly to eliminate the possibility of $\mathrm{S}$ deficiency. Thus, even though $\mathrm{S}$ did not limit plant growth the $\mathrm{KCl}, \mathrm{K}_{2} \mathrm{SO}_{4}$ and $\mathrm{N}$ fertilizer treatments collectively had considerable effect on petiole$\mathrm{SO}_{4}$ concentrations.

Fertilizer-K increased petiole-K at all petiole sampling times (Fig. 4). Fertilizer-N decreased petiole-K at zero fertilizer-K (probably a dilution effect) but increased petiole-K in the presence of $\mathrm{KCl}$. The positive effect of soil $\mathrm{N}$ on plant $\mathrm{K}$ became more pronounced over the growing season. With fertilizer $\mathrm{K}_{2} \mathrm{SO}_{4}$ there was a slight but significant positive effect of fertilizer$\mathrm{N}$ on petiole K (Fig. $4 \mathrm{~d}$ ).

Petiole-Ca concentration increased with sampling time and decreased slightly with fertilizer-K and $\mathrm{N}$ (Fig. 5). The treatment effects were more 

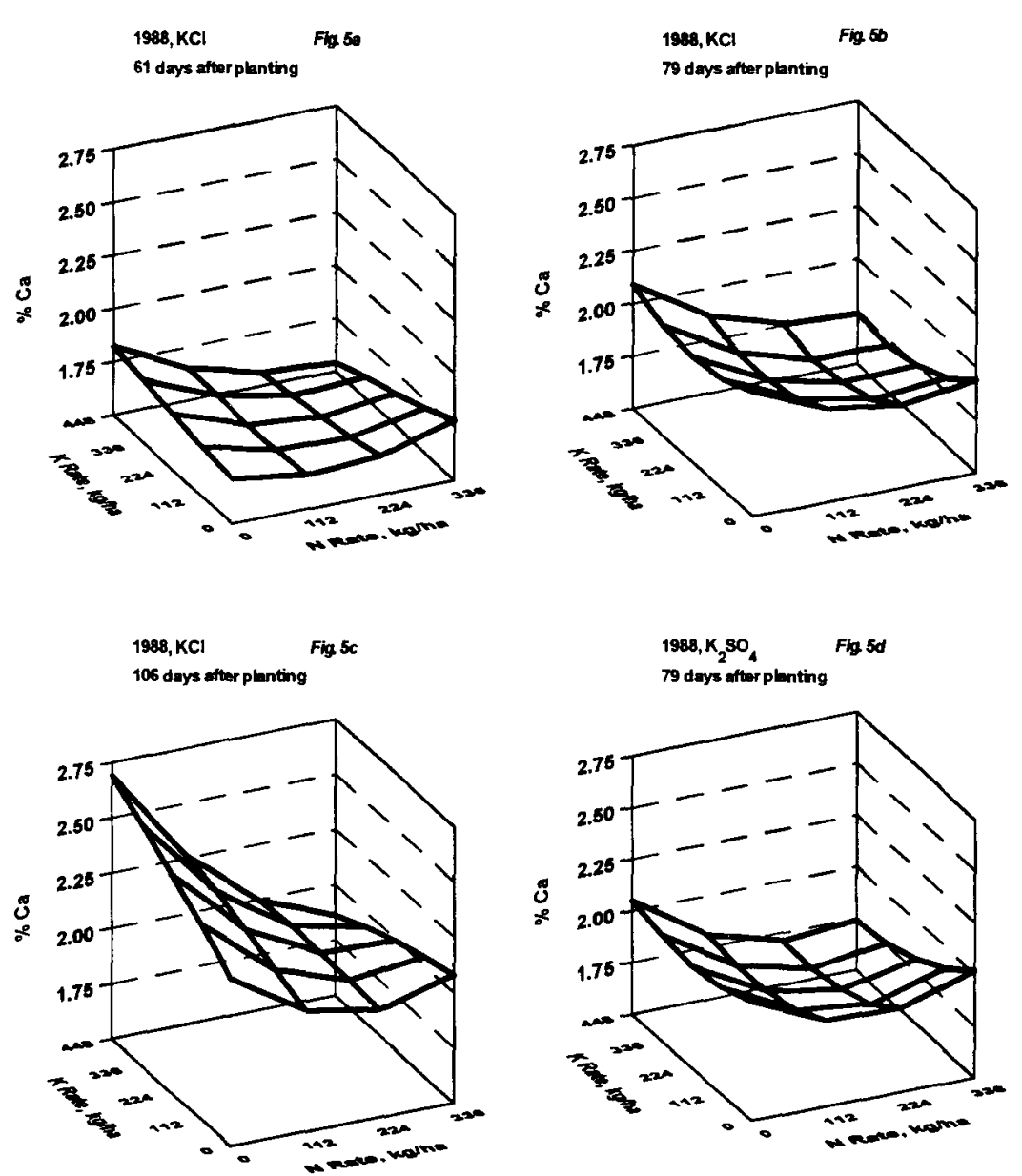

FIG. 5. Petiole Ca responses to $\mathrm{N}$ and $\mathrm{KCl}(\mathrm{a}, \mathrm{b}, \mathrm{c})$ and $\mathrm{K}_{2} \mathrm{SO}_{4}$ (d) fertilizers at selected sampling times in 1988.

significant for the last sampling in 1988 (Table 3). Figure 5c shows that late-sampled petiole-Ca increased sharply with $\mathrm{KCl}$ where soil $\mathrm{N}$ was low. Thus, the otherwise simple negative interaction between $\mathrm{K}$ and $\mathrm{Ca}$ was confounded markedly by fertilizer-KCl. The potato plant seemed to balance increased petiole-Cl with petiole-Ca. Potassium sulfate had no effect at zero fertilizer- $\mathrm{N}$ on petiole-Ca but at $336 \mathrm{~kg} \mathrm{~N} / \mathrm{ha}$ fertilizer-K decreased petiole$\mathrm{Ca}$ (Fig. 5d). Overall, a complex interaction involving cationic and anionic charge balancing is evident. This is discussed further below.

Petiole-Mg increased with sampling time and decreased to some extent with fertilizer-K (Fig. 6). Fertilizer-N tended to increase petiole-Mg at zero fertilizer- $\mathrm{K}$, the tendency decreasing with increasing fertilizer $\mathrm{K}$. The $\mathrm{KCl}$ and $\mathrm{K}_{2} \mathrm{SO}_{4}$ effects were very similar. The effect of $\mathrm{KCl}$ on petiole-Ca did not 

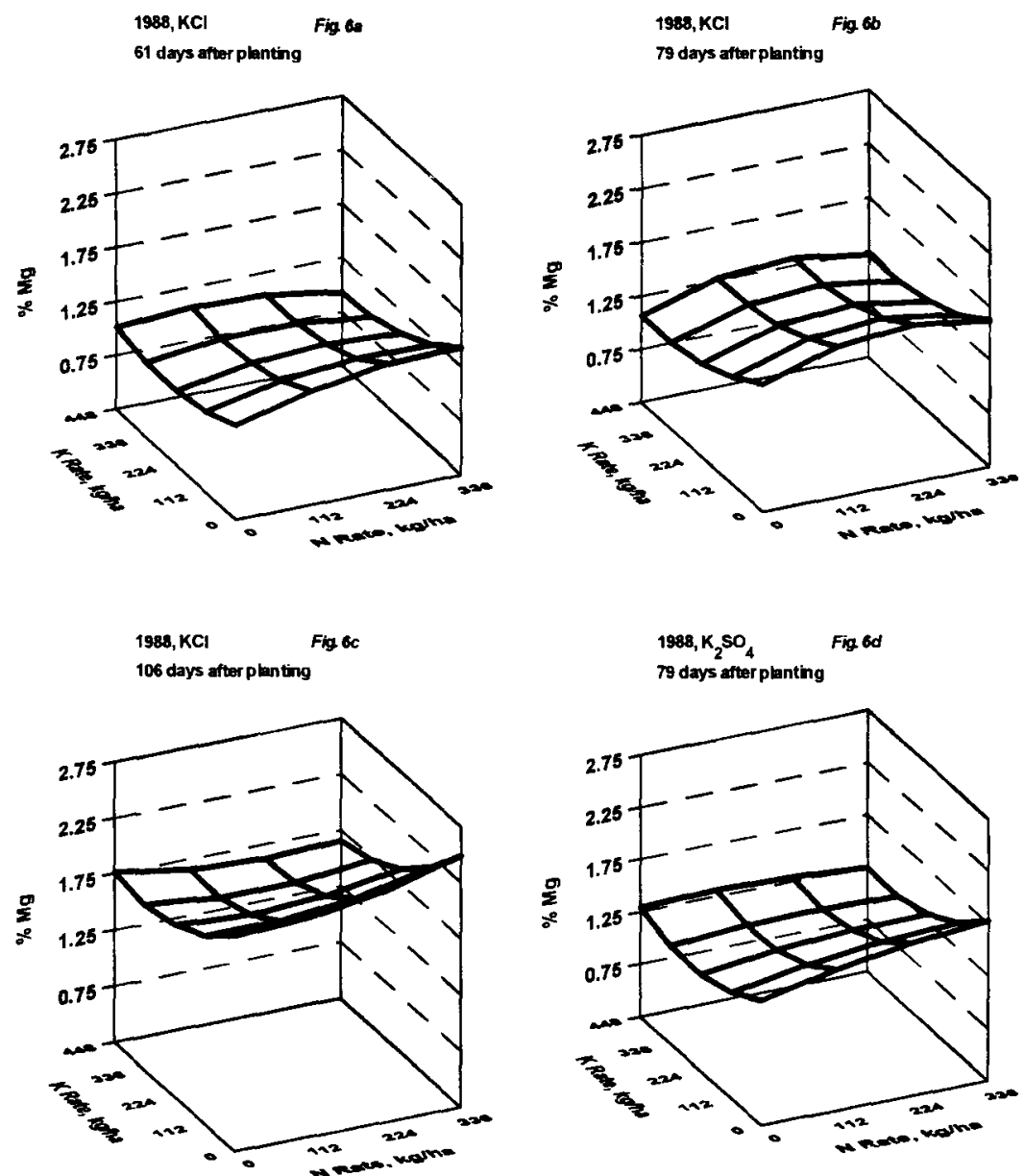

FIG. 6. Petiole $\mathrm{Mg}$ responses to $\mathrm{N}$ and $\mathrm{KCl}(\mathrm{a}, \mathrm{b}, \mathrm{c})$ and $\mathrm{K}_{2} \mathrm{SO}_{4}(\mathrm{~d})$ fertilizers at selected sampling times in 1988.

occur with petiole-Mg (Fig. 5 vs 6 ).

Despite the fact that $\mathrm{K}, \mathrm{Mg}$ and $\mathrm{Ca}$ concentrations in petioles varied markedly among fertilizer treatments and over time, the sum of these cations was constant; the response surface was essentially flat for all sampling times (data not shown). By contrast there were highly significant treatment effects on the sum of anions $\left(\mathrm{NO}_{3}, \mathrm{Cl}, \mathrm{SO}_{4}\right)$. The summation of nutrient antagonisms and synergisms are given in Fig. 7, which relates the ratio $\Sigma$ Cations/ $\Sigma$ Anions to $\mathrm{N}$ and $\mathrm{K}$ soil treatments. The ion ratio increased with sampling time (Fig. 7). The ratio generally decreased with $\mathrm{KCl}$ but the response surface conformation markedly differed with $\mathrm{K}_{2} \mathrm{SO}_{4}$ (Fig. 7c vs 7d).

The effects of $\mathrm{K}$ fertilizer on $\mathrm{Mg}$ and $\mathrm{Ca}$ concentrations of potato petioles warrant further evaluation to determine if, for example, $\mathrm{K}$ fertilization 

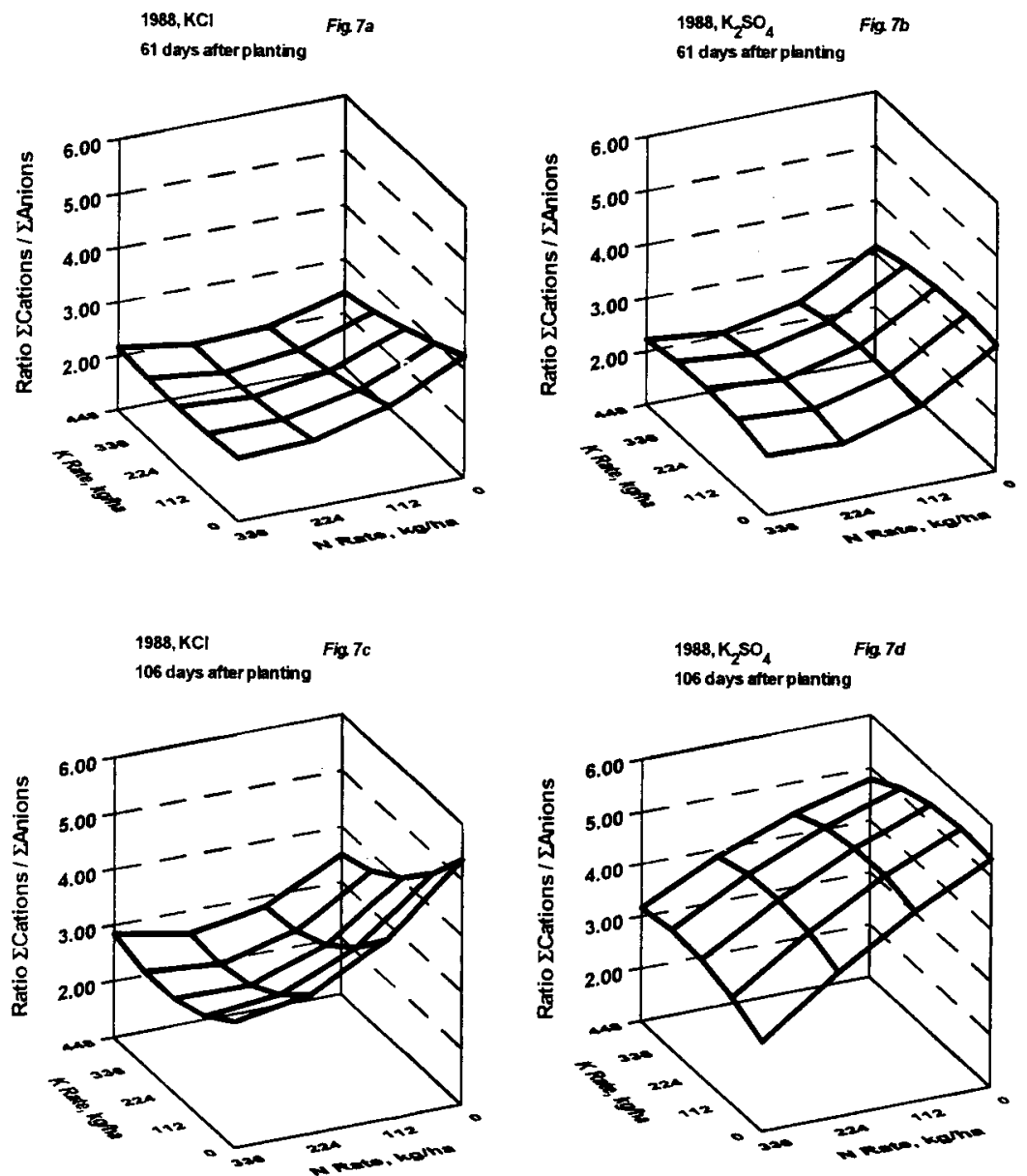

FIG. 7. Petiole $\Sigma$ Cations/ $\sum$ Anions ratio responses to $\mathrm{N}$ and $\mathrm{KCl}(\mathrm{a}, \mathrm{c})$ and $\mathrm{K}_{2} \mathrm{SO}_{4}$ fertilizers at selected sampling times in 1988.

could induce $\mathrm{Mg}$ deficiency in soil derived from dolomite (i.e. high levels of available $\mathrm{Mg}$ ) even though $\mathrm{N}$ fertilization induced higher $\mathrm{Mg}$ uptake. A study examining the K-Mg-plant relations would need to be carefully designed to segregate the various synergistic and antagonistic interactions on plant nutrient element composition.

The uniformity of $\Sigma$ Cations across $\mathrm{N}$ and $\mathrm{K}$ fertilizer levels and time demonstrate (a) that potato adapts readily to general environmental nutrient conditions, and (b) that osmolality of plant cells probably is as important as direct nutritional effects of the individual nutrient elements on plant growth vigor.

Some workers $(16,19)$ associated increased organic anion production in the plant (i.e. $\Sigma$ Cations - $\Sigma$ Anions) with increased plant yield. In those stud-

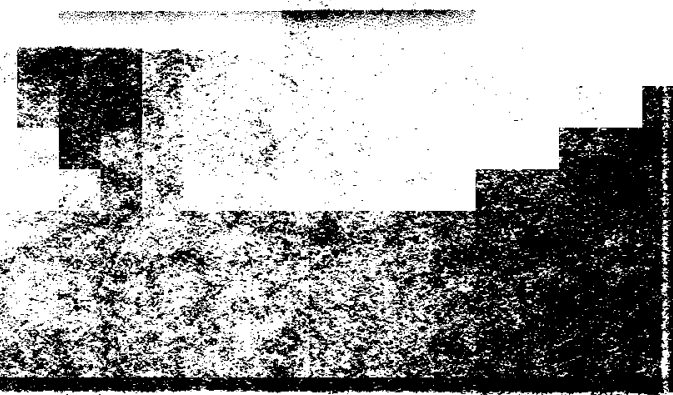


ies organic ion production decreased with $\mathrm{KCl}$ fertilization in a manner similar to our results. It is apparent that, an exclusive focus on cation-anion balance may ignore the antagonism between $\mathrm{NO}_{3}$ and $\mathrm{Cl}$ and associated changes in the $\mathrm{N}$ economy of the plant. Apparent yield differences related to organic anions would be obviated if the $\mathrm{NO}_{3}-\mathrm{Cl}$ antagonism was operating.

The N-K soil treatments did not affect petiole-P concentration, which averaged $0.220 \%$ or $0.213 \mathrm{mmol} / \mathrm{g}$ over the two seasons. Including $\mathrm{PO}_{4}-\mathrm{P}$ in the $\Sigma$ Anions would uniformly increase $\Sigma$ Anions by about $16 \%$ and decrease the ratio $\Sigma$ Cations $/ \Sigma$ Anions by about $14 \%$. But with or without petiole$\mathrm{P} \Sigma$ Cations was three to five times larger than $\Sigma$ Anions overall. Presumably the difference in ionic electrical charge was balanced by the production of organic acid anions within the plant (16). Evidently $\mathrm{Cl}$ decreased the production of organic anions, in agreement with Flowers (2), perhaps because $\mathrm{Cl}$ substitutes for organic anions in the plant. Figure 7 shows that fertilizer$\mathrm{S}$ had a similar but somewhat smaller effect.

The lack of petiole-P concentration effects by $\mathrm{N}, \mathrm{K}, \mathrm{S}$ or $\mathrm{Cl}$ fertilizer levels, contrast with work of Hiatt and Leggett (6) who reported that plant $P$ concentration depended on other nutrient anions in the rooting medium. Our results might have been different if soil-P was a controlled experimental variable that limited plant growth in some of the treatments. Unpublished data at Logan, Utah show that $P$ fertilization of a low-P soil had a strong positive effect on $\mathrm{Mg}$ and $\mathrm{Na}$ composition of alfalfa.

Correlations between petiole $\mathrm{N}$ and $\mathrm{K}$ and tuber yield and specific gravity were described and discussed by Westermann et al. (20).

\section{Conclusions}

1. Nitrogen, $\mathrm{K}$, and Cl fertilization of Russett Burbank potato grown on a highly calcareous, low-K and low-Cl soil had complex effects on petiole chemistry. The most important of these was the mutual antagonism between $\mathrm{NO}_{3}$ and $\mathrm{Cl}$, which was clearly demonstrated in this low-Cl environment. The results suggest that petiole- $\mathrm{NO}_{3}$ is difficult to interpret when the other environmental nutrient conditions are not well characterized.

2. There was a strong positive effect of soil $\mathrm{N}$ fertility on $\mathrm{K}$ and $\mathrm{Mg}$ concentration of potato petioles. This interaction was weak to non-existent for $\mathrm{Ca}$. On the other hand, there was strong competition between $\mathrm{K}$ and $\mathrm{Mg}$, and somewhat weak competition between $\mathrm{K}$ and $\mathrm{Ca}$ in this calcareous soil. Nevertheless, the sum of petiole cation concentrations (expressed as $\mathrm{mmol}_{\mathrm{c}} / \mathrm{g}$ ) was constant across petiole sampling times and soil fertility levels. Evidently, potato has a considerable ability to adjust the osmotica of its vascular system, and probably the osmotica of other organs as well.

3. The sum of inorganic anions in the petiole (i.e. $\mathrm{NO}_{3}, \mathrm{Cl} \mathrm{SO}_{4}$ ) was highly sensitive to soil $\mathrm{N}, \mathrm{K}$ and $\mathrm{Cl}$ fertility levels. The ratio of inorganic cations to anions in the petiole ranged from 3 to 5 , indicating that the 
plant produced considerable amounts of organic anions to maintain the ionic charge balance.

4. The incomplete factorial experimental design used in this series of experiments was very efficient in relation to field space and other resources versus the amount of information developed. This statistical tool is particularly useful in evaluating the complex soil fertility-plant nutrient interactions that occur in the field.

\section{Literature Cited}

1. Broyer, T.C., A.B. Carlton, C.M. Johnson and P.R. Stout. 1954. Chlorine-A micro-nutrient element for higher plants. Plant Phys 29:526-532.

2. Flowers, T.J. 1988. Chloride as a nutrient and as an osmoticum. Adv Plant Nutr 3:55-78.

3. Glass, A.D.M. and M.Y. Siddiqui. 1985. Nitrate inhibition of chloride influx in barley: Implications for a proposed chloride homeostat. J Expt Botany 36:556-566.

4. Gausman, H.W., E.G. Corbett and R.A. Struchtemeyer. 1958. Chloride deficiency symptoms in potato plants. Agron J 50:403.

5. Geraldson, C.M. and K.B. Tyler. 1990. Plant analysis as an aid in fertilizing vegetable crops. In: R. L. Westerman (ed). Soil testing and plant analysis, Third Edition. pp. 549-562. Soil Science Society of America. Madison, Wisconsin.

6. Hiatt, A.J. and J.E. Leggett. 1971. Jonic interactions and antagonisms in plants. In: E. W. Carson (ed). The Plant Root and Its Environment. pp 101-134. University Press of Virginia, Charlottesville.

7. James, D.W., W.H. Weaver and R.L. Reeder. 1970. Chloride uptake by potatoes and the effects of potassium chloride and phosphorus fertilization. Soil Sci 109:48-52.

8. James, D.W., D.C. Kidman, W.H. Weaver and R.L. Reeder. 1970. Factors affecting chloride uptake and implications of the chloride-nitrate interaction in sugarbeet mineral nutrition. Jour Am Soc Sugarbeet Tech 15:647-656.

9. James, D.W. 1990. Plant nutrient interactions in alkaline and calcareous soils. In: V.C. Baligar and R.R. Duncan (eds), Crops as Enhancers of Nutrient Use. Academic Press, New York, NY.

10. Kafkafi, U., N. Valoras and J. Letey. 1982. Chloride interaction with nitrate and phosphate nutrition in tomato (Lycopersicum esculentum L.). J Plant Nutr 5:1369-1385.

11. Kitson, R.E. and M.G. Mellon. 1944. Colorimetric determination of phosphorus as molydivanado phosphoric acid. Ind Eng Chem Anal Ed 16:379.

12. Latchat Instruments. 1988. 6645 West Mill Road, Milwaukee, WI 53218-1239, USA.

13. Milham, P.J., A.S. Awad, R.E. Paul and J.H. Bull. 1970. Analysis of plants, soils and waters for nitrate using an ion-selective electrode. Analyst 95:751-757.

14. Moraghan, J.T. 1987. Nitrogen fertilizer effects on uptake and partitioning of chloride in sugarbeet plants. Agron J 79:10541057.

15. Munson, R.D. and W.L. Nelson. 1990. Principles and practices in plant analysis. In: R. L. Westerman (ed). Soil testing and plant analysis, Third Edition. Soil Science Society of America. Madison, Wisconsin.

16. Noggle, J.C. 1966. Ionic balance and growth of sixteen plant species. Soil Sci Soc Am Proc 30:763-766.

17. Parker, M.B., G.J. Gascho and T.P. Gaines. 1983. Cl toxicity of soybeans grown on Atlantic coast Flatwood soils. Agron J 75:439-443. 
18. Smith, G.S., C.J. Clark and P.T. Holland. 1987. Chlorine requirements of kiwifruit. New Phytologist 106:71-80.

19. Watanabe, F.W., S.R. Olsen and C.V. Cole. 1971. Ionic balance and growth of five plant species in four soils. Agron J 63:23-28.

20. Westermann, D.T., T.A. Tindall, D.W. James and R.L. Hurst. 1993. Nitrogen and potassium fertilization of potatoes: Yield and specific gravity. Am Potato J (in press).

21. Westermann, D.T., D.W. James, T.A. Tindall and R.L. Hurst. 1993. Nitrogen and potassium fertilization of potatoes: Tuber sugars and starch. Am Potato J (in press).

22. Whitehead, D.C. 1985. Chlorine deficiency in red clover grown in solution culture. J Plant Nutr 8:198-198.

23. Wiegel, R.D, Jr., J.A. Schillinger, B.A. McCaw, H.G. Gauch and E. Hsiao. 1973. Nutrientnitrate levels and the accumulation of chloride in leaves of snap beans and roots of soybeans. Crop Science 13:411-412. 


\section{CORRECTION}

Figure 1 was inadvertently run twice in the Leever, et al., article in the March (1994) issue of the APJ. Below is the correct Figure 2 to be inserted on page 139.

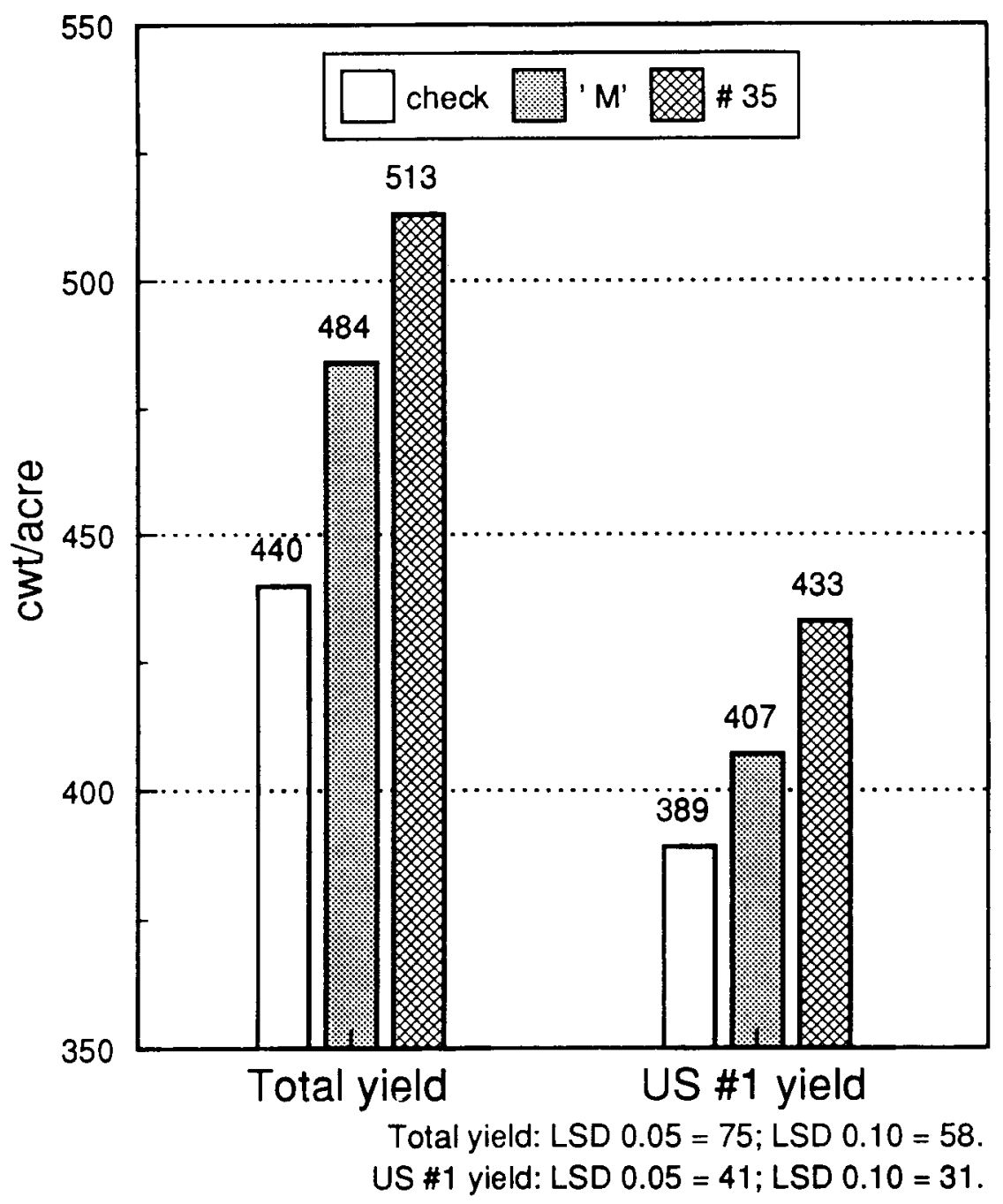

FIG. 2. Total and US\#1 yields of Norgold Russet Nebraska strains at Hermiston, Oregon. Excluded is strain \#19 (absent in 1 trial). 